\title{
Obtaining tissues and organs: empowering actions of nurses in the light of ecosystem thinking
}

\author{
Obtenção de tecidos e órgãos: ações potencializadoras do enfermeiro à luz do pensamento ecossistêmico
}

Obtención de tejidos y órganos: acciones potenciadoras del enfermero a la luz del pensamiento ecosistémico

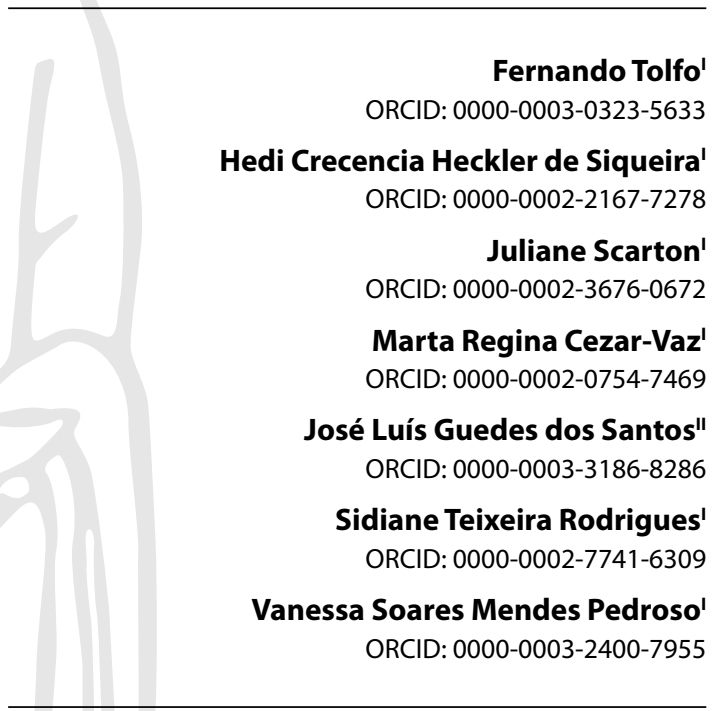

'Universidade Federal do Rio Grande. Rio Grande, Rio Grande do Sul, Brazil.

"Universidade Federal de Santa Catarina. Florianópolis, Santa Catarina, Brazil.

How to cite this article:

Tolfo F, Siqueira HCH, Scarton J, Cezar-Vaz MR, Santos JLG, Rodrigues ST, et al. Obtaining tissues and organs: empowering actions of nurses in the light of ecosystem thinking. Rev Bras Enferm. 2021;74(2):e20200983. https://doi.org/10.1590/0034-7167-2020-0983

\section{Corresponding author:} Fernando Tolfo E-mail: fernandotolfo@gmail.com

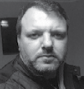

EDITOR IN CHIEF: Antonio José de Almeida Filho ASSOCIATE EDITOR: Hugo Fernandes

Submission: $09-25-2020$

Approval: 11-13-2020

\begin{abstract}
Objectives: to analyze, in the light of ecosystem thinking, the actions of nurses that stimulate the potential to increase the rates of organ and tissue donation. Methods: descriptive, exploratory, mixed method study, of the embedded type, with simultaneous realization and emphasis on the quantitative approach, including 125 nurses from the Intra-hospital Commission for Donation of Organs and Tissues for Transplants in the Southern Region of Brazil. Data were collected using an online survey questionnaire. Quantitative data were analyzed using the Statistical Package for the Social Sciences software; and qualitative, Bardin content analysis. Results: the identified actions refer to the reception of the family, exclusive dedication and remunerated valorization of the nurses of the commission, media and dissemination campaigns for society in general and educational actions for the training of professionals. Conclusions: the results of the actions encourage the possibility of increasing the rates of organ and tissue donation for transplantation.

Descriptors: Tissue and Organ Procurement; Nurses; Ecosystem; Work; Nurse's Role.
\end{abstract}

\section{RESUMO}

Objetivos: analisar, à luz do pensamento ecossistêmico, as ações do enfermeiro que estimulam a potencialidade de aumentar as taxas de doação de órgãos e tecidos. Métodos: estudo descritivo, exploratório, de método misto, do tipo incorporado, com realização simultânea e ênfase na abordagem quantitativa, incluindo 125 enfermeiros de Comissão Intra-hospitalar de Doação de Órgãos e Tecidos para Transplantes da Região Sul do Brasil. Os dados foram coletados por meio de questionário tipo survey on-line. Os dados quantitativos foram analisados utilizando o software Statistical Package for the Social Sciences; e os qualitativos, análise de conteúdo de Bardin. Resultados: as ações identificadas referem-se ao acolhimento do familiar, dedicação exclusiva e valorização remunerada dos enfermeiros da comissão, campanhas de mídia e divulgação para a sociedade em geral e ações educativas para capacitação dos profissionais. Conclusões: os resultados das ações estimulam a possibilidade de aumentar os índices de doação de órgãos e tecidos para transplante.

Descritores: Obtenção de Tecidos e Órgãos; Enfermeiras e Enfermeiros; Ecossistema; Trabalho; Papel do Enfermeiro.

\section{RESUMEN}

Objetivos: analizar, de acuerdo al pensamiento ecosistémico, las acciones del enfermero que estimulan la potencialidad de aumentar las tasas de donación de órganos y tejidos. Métodos: estudio descriptivo, exploratorio, de método misto, del tipo incorporado, con realización simultánea y énfasis en abordaje cuantitativo, incluyendo 125 enfermeros de Comisión Intra-hospitalaria de Donación de Órganos y Tejidos para Trasplantes de la Región Sur de Brasil. Los datos recogidos por medio de cuestionario tipo survey on-line. Datos cuantitativos analizados utilizando el software Statistical Package for the Social Sciences; y los cualitativos, análisis de contenido de Bardin. Resultados: acciones identificadas refieren a la recepción del familiar, dedicación exclusiva y valoración remunerada de los enfermeros de la comisión, campañas mediáticas y divulgación para la sociedad en general y acciones educativas para capacitación de los profesionales. Conclusiones: resultados de las acciones estimulan la posibilidad de aumentar los índices de donación de órganos y tejidos para trasplante. Descriptores: Obtención de Tejidos y Órganos; Enfermeras y Enfermeros; Ecosistema; Trabajo; Papel del Enfermero. 


\section{INTRODUCTION}

Etymologically, the word "ecosystem" is composed of the prefix "eco-", derived from the Greek "oîkos", which means house/ space/environment; and "system", a word originated from the Latin "sýstèma", which means a set of interdependent elements or organisms, in order to form an organized unit/totality. The understanding of systems and/or ecosystems was defined in the 1950s, by Ludwig Von Bertalanffy, based on studies and essays from theoretical and practical concepts of the notion of system, which were compiled and consolidated in the so-called General Systems Theory ${ }^{(1)}$.

The knowledge that emerged from this conceptual sphere led to a new way of thinking and acting in relation to the space where one lives. Given this knowledge, a new emerging paradigm was formed, represented by the so-called "systemic thinking", with which one stops studying only the object itself and emerges to decipher the relationships established between all the components that form a reality. Thus, the study of reality based on systemic thinking involves the principles of relationships, interactions, connections and interdependence, which occur between everything and all the elements that constitute reality ${ }^{(2)}$.

The ecosystem is, therefore, referred to as the set of living (biotic) and non-living (abiotic) elements that relate, interact in a limited space and time ${ }^{(2)}$. The hospital institution with its physical structure, services offered, actions taken, health professionals (including nurses), potential donors of organs and tissues for transplant and their families, participate as ecosystem elements in this work. components. It is worth mentioning that, often, the family is unaware of its own will regarding the intentions of being an organ donor or not, given that this issue goes unnoticed or does not exist in the conversations between its members ${ }^{(3-5)}$.

When brain death (BD) occurs, it is up to the families to answer an extremely delicate question, asked in a difficult and painful moment, which is the acceptance or not of the organ donation of their loved one. It is then considered that, when understanding the hospital as an ecosystem, there are infinite relationships between its component elements, thus expanding the perception of this "whole" that surrounds the organ donation process.

Among the elements inserted in the hospital environment, the Intra-hospital Commission for Donating Organs and Tissues for Transplants (CIHDOTT). It was created because of the need to obtain organs and tissues for transplants, which, according to the World Health Assembly, is insufficient to meet demand and is perceived as an important strategy in several countries, regardless of economic, technological or pharmacological resources ${ }^{(6)}$. In this sense, the search for alternatives aimed at increasing the number of organ donations has been targeted by governments, societies and health teams. As a strategy, $\mathrm{Cl}-$ HDOTTs have the function of assisting in the donation process, making the link between the other components of the National Transplant System with the assistance teams and the family, from the identification of the possible donor to the delivery of the body to the family members ${ }^{(7)}$.

CIHDOTTs emerged in Brazil from the year 2000 and are involved in the organ donation process, in order to actively search for possible donors, schedule rooms in the operating room, prepare and make available all material and specialized equipment, in addition to provide adequate human resources for the act. Also, it makes the link between the other elements of the National Transplant System (Organization and Procurement of Organs [OPOs] and the Central Transplant Center), as well as the interview with family members to request the donation ${ }^{(7)}$.

Among the components of CIHDOTTs, there is the nurse, referred to as a participant in the organ and tissue donation process and evidenced as an important professional for an efficient organ donation system; and, according to national and international surveys, it is the one pointed out as capable of carrying out actions that make it possible to increase the donation of organs and tissues in the hospitals where it operates ${ }^{(8-11)}$.

In Poland, it was found that the hiring of transplant nurse coordinators proved effective in $50 \%$ of hospitals ${ }^{(9)}$. Positive attitudes related to family members also seem to have an influence on the favorable outcome for organ donation, according to a study carried out in Intensive Care Units (ICUs) with French health professionals ${ }^{(10)}$ and students of Health Sciences in Turkey ${ }^{(11)}$. In the Netherlands, it was revealed that nurses play an important role in the family approach, as they are able to obtain the opinion of family members, even before the medical request for organ donation ${ }^{(8)}$. Still, a research carried out in Sweden registered that the positive attitudes of nurses in the donation process involve the experience of professional life, participation in conversations with relatives, taking care of people with BD and personal experiences in the donation process and/or organ transplantation of family members ${ }^{(12)}$.

Thus, evidencing the actions developed by CIHDOTTs nurse professionals can enable the promotion of organ and tissue donation for transplants.

\section{OBJECTIVES}

To analyze, in the light of ecosystem thinking, the actions of nurses that stimulate the potential to increase the rates of organ and tissue donation.

\section{METHODS}

\section{Ethical aspects}

The study was approved by the Research Ethics Committee of the Federal University of Rio Grande. The ethical precepts of Resolution No. 466/2012 of the National Health Council (CNS) were followed and respected during the entire process of the research.

\section{Study design, period and location}

It is a cross-sectional, descriptive and exploratory study, of the embedded type, using a mixed method approach, with simultaneous realization, emphasis on the quantitative approach and guided by the STROBE tool ${ }^{(13)}$. The combination of the data took place by incorporating qualitative and quantitative data, in the light of ecosystem thinking. This technique can also be described as a Mixed Method Notation method, whose schematic representation is conceived as QUAN (which) ${ }^{(14)}$. 
The data were collected from June to August 2019, having as location the states of the Southern Region of Brazil, which was chosen for: having 33\% of all CIHDOTTs in Brazil and being above the average organ donation for transplantation, the states of Santa Catarina and Paraná having similar rates to the countries with higher donation rates ${ }^{(15)}$.

\section{Population, inclusion and exclusion criteria}

The stipulated population was 185 nurses members of CIDOTTs in the South of Brazil, according to institutional data provided through Google Docs. A structured instrument was sent to them online, with 52 5-point Likert scale closed questions (always, often, sometimes, rarely and never) and five open questions. Of the guests, 125 nurses agreed to participate, returning the quantitative instrument duly completed. Regarding the qualitative part, which is not mandatory for the return of quantitative questions, 106 answers were obtained.

Inclusion criteria were considered, in the quantitative and qualitative part: being a nurse member of OPOs and CIHDOTTs of the public or private network of the South Region of the country, duly registered in class councils. In the quantitative part, those who were removed from professional practice at CIHDOTT at the time of data collection, due to vacation, health treatment or the like; and, in the qualitative part, the interviews not answered in full and interviews with simple answers that contained only isolated words, such as "yes", "no" and "for sure". 17 interviews were excluded due to incompleteness and 11 due to simple answers, totalling 78 .

It was decided to limit the number of participants to $30 \%$ in each scenario studied, since the returned questionnaires were not equal in number. Thus, the proportion rule was applied, resulting in 7 participants from Paraná, 8 from Santa Catarina and 8 from Rio Grande do Sul, totalling 23 for qualitative analysis. To choose the inclusion of the participants, random probability sampling was applied, respecting the proportionality and representativeness of each state.

\section{Study protocol}

In order to know the population of this study, stipulated in 185 nurses, contact was made with the Transplant Centers of the States and with the OPOs of the states of the Southern Region of Brazil. An online questionnaire was generated in the Google Forms application, which is free and considered easy to handle and apply, used on the web to collect information through forms. Responses are sent directly to a spreadsheet set up for easy analysis, and data is automatically saved and stored in the user's Google Drive ${ }^{(16)}$.

The responses sent by the participants were automatically gathered in a spreadsheet in the cloud, which can therefore be viewed online or exported to spreadsheet software such as Microsoft Excel, allowing for easier data analysis, or to statistical analysis software such as the SPSS ${ }^{(17)}$. The questionnaire included quantitative closed questions, with 52 variables in total, and, for the purposes of this study, four variables were used that sought to examine the educational actions developed by CIHDOTTs; and ten on the care actions for the possible donor and his family, reported in Tables 1 and 2 .

The qualitative open questions were composed of five open themes, elaborated in order to obtain data from the participants on the nurses' previous training before they joined CIHDOTT; factors and barriers that hinder organ donation; facilitating factors in the organ donation process; actions that, in hospitals, are developed and have the potential to increase organ donation; as well as opinion related to the family interview.

After adapting the instrument to Google Forms, a questionnaire link was generated and sent online to potential interviewees through the state's OPOs and Transplant Centers. The method used allowed the interviewee, when opening the link, to view a screen that precedes the questionnaire, informing him about the need to fill out the Free and Informed Consent Form and, then, to allow the questionnaire to proceed. The nurse, upon accepting to participate in the research, was invited to add his email, confirming his acceptance. With this procedure, confidentiality and voluntary acceptance of participants were respected.

\section{Analysis of results and statistics}

For the analysis of quantitative data, the SPSS software, version 25, was used. The chi-square test, one-way ANOVA test and the Kolmogorov Smirnov test were performed. A significance level of 0.05 was established for all analyzes performed. A 95\% confidence level and a sampling error of $5 \%$ were defined, based on the estimated population of 185 nurses, applying the formula for the sample calculation ${ }^{(18)}$. Qualitative data were analyzed through content analysis by Bardin ${ }^{(19)}$, which originated units of records capable of deepening the participants' subjective knowledge by relating them to pre-existing quantitative categories, resulting in five other categories.

\section{RESULTS}

The data in this article includes the category "CIHDOTT nurses' actions that can enhance the donation of organs and tissues for transplantation", analyzed in the light of ecosystem thinking, seeking to understand the multiple facets of the actions that nurses in the Southern Region of Brazil consider important to increase organ and tissue donation rates. In this sense, actions related to family care were considered capable of increasing organ donation rates. (Table 1 ).

The actions related to family reception were corroborated by the nurses participating in the study as something that needs to be built and that makes it possible to increase the rates of organ donation:

Humanized and early family care. (P2 - Santa Catarina)

Improve reception conditions for family members. (P4 - Rio Grande do Sul)

Reception Model. (P5 - Santa Catarina) 
Table 1 - Actions of Intra-hospital Commission for Donating Organs and Tissues for Transplants nurses aimed at family reception, in the states of the Southern Region of Brazil, ( $N=125)$, Brazil, 2019

\begin{tabular}{|c|c|c|c|c|c|c|c|c|c|}
\hline \multirow[t]{2}{*}{ Variables } & \multicolumn{2}{|c|}{ General } & \multicolumn{2}{|c|}{ Paraná } & \multicolumn{2}{|c|}{$\begin{array}{l}\text { Santa } \\
\text { Catarina }\end{array}$} & \multicolumn{2}{|c|}{$\begin{array}{l}\text { Rio } \\
\text { Grande } \\
\text { do Sul }\end{array}$} & \multirow[t]{2}{*}{$p$ value } \\
\hline & $\mathbf{n}$ & $\%$ & $\mathbf{n}$ & $\%$ & n & $\%$ & $n$ & $\%$ & \\
\hline \multicolumn{10}{|c|}{$\begin{array}{l}1.1 \text { In the hospital where you work, are there technological, pharmacological, spiritual } \\
\text { and / or psychological and structural supports (room for family interviews, for example), } \\
\text { necessary for the maintenance of the potential donor and family support? }\end{array}$} \\
\hline Always & 51 & 40.8 & 19 & 51.4 & 24 & 50 & 8 & 20 & \multirow{5}{*}{$0.006^{*}$} \\
\hline Often & 34 & 27.2 & 10 & 27 & 14 & 29.2 & 10 & 25 & \\
\hline Sometimes & 27 & 21.6 & 3 & 8.1 & 7 & 14.6 & 17 & 42.5 & \\
\hline Rarely & 11 & 8.8 & 4 & 10.8 & 2 & 4.2 & 5 & 12.5 & \\
\hline Never & 2 & 1.6 & 1 & 2.7 & 1 & 2.1 & 0 & 0 & \\
\hline \multicolumn{10}{|c|}{$\begin{array}{l}\text { 1.2 Do you promote and organize the reception to donor families before, during and after } \\
\text { the entire donation process within the institution? }\end{array}$} \\
\hline Always & 81 & 64.8 & 26 & 70.3 & 36 & 75 & 19 & 47.5 & \multirow{5}{*}{0.101} \\
\hline Often & 33 & 26.4 & 7 & 18.9 & 11 & 22.9 & 15 & 37.5 & \\
\hline Sometimes & 7 & 5.6 & 2 & 5.4 & 1 & 2.1 & 4 & 10 & \\
\hline Rarely & 4 & 3.2 & 2 & 5.4 & 0 & 0 & 2 & 5 & \\
\hline Never & 0 & 0 & 0 & 0 & 0 & 0 & 0 & 0 & \\
\hline \multicolumn{10}{|c|}{ 1.3 Are you in constant telephone contact with your family for any information? } \\
\hline Always & 67 & 53.6 & 18 & 48.6 & 30 & 62.5 & 19 & 47.5 & \multirow{5}{*}{0.333} \\
\hline Often & 37 & 29.6 & 15 & 40.5 & 11 & 22.9 & 11 & 27.5 & \\
\hline Sometimes & 11 & 8.8 & 1 & 2.7 & 4 & 8.3 & 6 & 15 & \\
\hline Rarely & 7 & 5.6 & 2 & 5.4 & 3 & 6.3 & 2 & 5 & \\
\hline Never & 3 & 2.4 & 1 & 2.7 & 0 & 0 & 2 & 5 & \\
\hline \multicolumn{10}{|c|}{ 1.4 When participating in the donation process, are you present throughout the process? } \\
\hline Always & 70 & 56 & 20 & 54.1 & 34 & 70.8 & 16 & 40 & \multirow{5}{*}{$0.024^{*}$} \\
\hline Often & 39 & 31.2 & 13 & 35.1 & 11 & 22.9 & 15 & 37.5 & \\
\hline Sometimes & 13 & 10.4 & 2 & 5.4 & 3 & 6.3 & 8 & 20 & \\
\hline Rarely & 2 & 1.6 & 2 & 5.4 & 0 & 0 & 0 & 0 & \\
\hline Never & 1 & 0.8 & 0 & 0 & 0 & 0 & 1 & 2.5 & \\
\hline \multicolumn{10}{|c|}{$\begin{array}{l}\text { 1.5 Do you, when conducting the interview with family members, follow a specific } \\
\text { methodology and focus on the possibility of accepting the donation? }\end{array}$} \\
\hline Always & 61 & 48.8 & 20 & 54.1 & 27 & 56.3 & 14 & 35 & \multirow{5}{*}{0.052} \\
\hline Often & 36 & 28.8 & 6 & 16.2 & 15 & 31.3 & 15 & 37.5 & \\
\hline Sometimes & 16 & 12.8 & 5 & 13.5 & 2 & 4.2 & 9 & 22.5 & \\
\hline Rarely & 8 & 6.4 & 3 & 8.1 & 3 & 6.3 & 2 & 5 & \\
\hline Never & 4 & 3.2 & 3 & 8.1 & 1 & 2.1 & 0 & 0 & \\
\hline $\begin{array}{l}\text { 1.6 Do you resp } \\
\text { share your opin }\end{array}$ & & & & & & & & & \\
\hline Always & 77 & 61.6 & 28 & 75.7 & 33 & 68.8 & 16 & 40 & \\
\hline Often & 37 & 29.6 & 7 & 18.9 & 13 & 27.1 & 17 & 42.5 & \\
\hline Sometimes & 9 & 7.2 & 1 & 2.7 & 2 & 4.2 & 6 & 15 & $0.023^{*}$ \\
\hline Rarely & 2 & 1.6 & 1 & 2.7 & 0 & 0 & 1 & 2.5 & \\
\hline Never & 0 & 0 & 0 & 0 & 0 & 0 & 0 & 0 & \\
\hline $\begin{array}{l}\text { 1.7 Do you try t } \\
\text { continue to live }\end{array}$ & & & & & & & & & \\
\hline Always & 110 & 88 & 32 & 86.5 & 42 & 87.5 & 36 & 90 & \\
\hline Often & 11 & 8.8 & 4 & 10.8 & 6 & 12.5 & 1 & 2.5 & \\
\hline Sometimes & 2 & 1.6 & 0 & 0 & 0 & 0 & 2 & 5 & 0.175 \\
\hline Rarely & 1 & 0.8 & 1 & 2.7 & 0 & 0 & 0 & 0 & \\
\hline Never & 1 & 0.8 & 0 & 0 & 0 & 0 & 1 & 2.5 & \\
\hline $\begin{array}{l}1.8 \text { When interv } \\
\text { cause more pair }\end{array}$ & & & & & & & & & \\
\hline Always & 60 & 48 & 21 & 56.8 & 26 & 54.2 & 13 & 32.5 & \\
\hline Often & 25 & 20 & 6 & 16.2 & 8 & 16.7 & 11 & 27.5 & \\
\hline Sometimes & 22 & 17.6 & 6 & 16.2 & 6 & 12.5 & 10 & 25 & 0.504 \\
\hline Rarely & 12 & 9.6 & 3 & 8.1 & 5 & 10.4 & 4 & 10 & \\
\hline Never & 6 & 4.8 & 1 & 2.7 & 3 & 6.3 & 2 & 5 & \\
\hline $\begin{array}{l}1.9 \text { Are there su } \\
\text { support or socia }\end{array}$ & & & & & & & & & \\
\hline Always & 52 & 41.6 & 19 & 51.4 & 22 & 45.8 & 11 & 27.5 & \\
\hline Often & 35 & 28 & 10 & 27 & 16 & 33.3 & 9 & 22.5 & \\
\hline Sometimes & 25 & 20 & 4 & 10.8 & 8 & 16.7 & 13 & 32.5 & 0.058 \\
\hline Rarely & 11 & 8.8 & 4 & 10.8 & 2 & 4.2 & 5 & 12.5 & \\
\hline Never & 2 & 1.6 & 0 & 0 & 0 & 0 & 2 & 5 & \\
\hline
\end{tabular}




\begin{tabular}{|c|c|c|c|c|c|c|c|c|c|}
\hline \multirow[t]{2}{*}{ Variables } & \multicolumn{2}{|c|}{ General } & \multicolumn{2}{|c|}{ Paraná } & \multicolumn{2}{|c|}{$\begin{array}{c}\text { Santa } \\
\text { Catarina }\end{array}$} & \multicolumn{2}{|c|}{$\begin{array}{c}\text { Rio } \\
\text { Grande } \\
\text { do Sul }\end{array}$} & \multirow[t]{2}{*}{$p$ value } \\
\hline & $\mathbf{n}$ & $\%$ & $\mathbf{n}$ & $\%$ & $\mathbf{n}$ & $\%$ & $\mathbf{n}$ & $\%$ & \\
\hline \multicolumn{10}{|c|}{ 1.10 Do you feel prepared to take a family approach and answer family questions? } \\
\hline Always & 56 & 44.8 & 22 & 59.5 & 18 & 37.5 & 16 & 40 & \\
\hline Often & 38 & 30.4 & 5 & 13.5 & 19 & 39.6 & 14 & 35 & \\
\hline Sometimes & 24 & 19.2 & 7 & 18.9 & 9 & 18.8 & 8 & 20 & 0.124 \\
\hline Rarely & 5 & 4 & 1 & 2.7 & 2 & 4.2 & 2 & 5 & \\
\hline Never & 2 & 1.6 & 2 & 5.4 & 0 & 0 & 0 & 0 & \\
\hline TOTAL & 125 & 100 & 37 & 100 & 47 & 100 & 40 & 100 & \\
\hline
\end{tabular}

Note: * $p$ estatisticamente significante: $p \leq 0,05$.

The ineffectiveness or the lack of adequate reception can negatively impact the donation process, implying difficulties. Data from Table 1 show that, compared to the other investigated states, Rio Grande do Sul still lacks a physical structure to better accommodate the relatives of potential organ donors.

[...] thinking about welcoming the capture of corneas, organs, a little more difficult, due to the profile. (P7 - Santa Catarina)

Only the family approach is made. (P8 - Rio Grande do Sul)

Improve reception conditions for family members. (P4 - Rio Grande do Sul)

Publicity and media campaigns were also identified as actions that can increase the rates of obtaining organs and tissues for transplant purposes, as shown in Table 2.
Education through campaigns, media and dissemination about organ donation can sensitize society and families to talk more about this subject and to get to know it better, as can be seen in the participants' reports:

Yes, especially if you leave the hospital and have more publicity. (P2 - Rio Grande do Sul)

The campaign we did in some months of the year, addressing employees, patients and family. (P3 - Rio Grande do Sul)

Show that organ trafficking does not happen, preferences for those who have a better financial condition. Disclose that it is a single queue. (P3 - Paraná)

Raising the awareness of all hospital employees. (P4 - Santa Catarina)

Table 2 - Educational actions carried out by Intra-hospital Commission for Donating Organs and Tissues for Transplants nurses in the South of Brazil, Brazil, 2019

\begin{tabular}{|c|c|c|c|c|c|c|c|c|c|}
\hline \multirow[t]{2}{*}{ Variables } & \multicolumn{2}{|c|}{ General } & \multicolumn{2}{|c|}{ Paraná } & \multicolumn{2}{|c|}{$\begin{array}{l}\text { Santa } \\
\text { Catarina }\end{array}$} & \multicolumn{2}{|c|}{$\begin{array}{l}\text { Rio } \\
\text { Grande } \\
\text { do Sul }\end{array}$} & \multirow[t]{2}{*}{$p$ value } \\
\hline & $\mathbf{n}$ & $\%$ & $\mathbf{n}$ & $\%$ & $\mathbf{n}$ & $\%$ & $\mathbf{n}$ & $\%$ & \\
\hline \multicolumn{10}{|c|}{$\begin{array}{l}\text { 2.1 Does your hospital's CIHDOTT give lectures on organ donation and transplants to } \\
\text { professionals in hospital units that serve neurocritical users? }\end{array}$} \\
\hline Always & 19 & 15.2 & 9 & 24.3 & 5 & 10.4 & 5 & 12.5 & \multirow{5}{*}{0.655} \\
\hline Often & 44 & 35.2 & 13 & 35.1 & 16 & 33.3 & 15 & 37.5 & \\
\hline Sometimes & 44 & 35.2 & 10 & 27 & 21 & 43.8 & 13 & 32.5 & \\
\hline Rarely & 14 & 11.2 & 4 & 10.8 & 4 & 8.3 & 6 & 15 & \\
\hline Never & 4 & 3.2 & 1 & 2.7 & 2 & 4.2 & 1 & 2.5 & \\
\hline \multicolumn{10}{|c|}{ 2.2 Does CIHDOTT give lectures at schools or universities? } \\
\hline Always & 20 & 16 & 6 & 16.2 & 7 & 14.6 & 7 & 17.5 & \multirow{5}{*}{0.694} \\
\hline Often & 18 & 14.4 & 3 & 8.1 & 7 & 14.6 & 8 & 20 & \\
\hline Sometimes & 32 & 25.6 & 8 & 21.6 & 13 & 27.1 & 11 & 27.5 & \\
\hline Rarely & 32 & 25.6 & 13 & 35.1 & 13 & 27.1 & 6 & 15 & \\
\hline Never & 23 & 18.4 & 7 & 18.9 & 8 & 16.7 & 8 & 20 & \\
\hline \multicolumn{10}{|c|}{$\begin{array}{l}\text { 2.3 Do you encourage professionals from the hospital units (ICU, Block, Emergency or others) } \\
\text { to participate in events, congresses, lectures that deal with guidelines and education for organ } \\
\text { donation? }\end{array}$} \\
\hline Always & 49 & 39.2 & 14 & 37.8 & 24 & 50 & 11 & 27.5 & \multirow{5}{*}{0.561} \\
\hline Often & 42 & 33.6 & 12 & 32.4 & 14 & 29.2 & 16 & 40 & \\
\hline Sometimes & 23 & 18.4 & 8 & 21.6 & 7 & 14.6 & 8 & 20 & \\
\hline Rarely & 10 & 8 & 3 & 8.1 & 3 & 6.3 & 4 & 10 & \\
\hline Never & 1 & 0.8 & 0 & 0 & 0 & 0 & 1 & 2.5 & \\
\hline \multicolumn{10}{|c|}{ 2.4 Do you use scientific knowledge to ensure that your organ donation work is evidence-based? } \\
\hline Always & 81 & 64.8 & 25 & 67.6 & 31 & 64.6 & 25 & 62.5 & \multirow{6}{*}{0.759} \\
\hline Often & 31 & 24.8 & 8 & 21.6 & 12 & 25 & 11 & 27.5 & \\
\hline Sometimes & 9 & 7.2 & 2 & 5.4 & 3 & 6.3 & 4 & 10 & \\
\hline Rarely & 3 & 2.4 & 2 & 5.4 & 1 & 2.1 & 0 & 0 & \\
\hline Never & 1 & 0.8 & 0 & 0 & 1 & 2.1 & 0 & 0 & \\
\hline TOTAL & 125 & 100 & 37 & 100 & 47 & 100 & 40 & 100 & \\
\hline
\end{tabular}

Note: CIHDOTT - Intra-hospital Committee for Donation of Organs and Tissues for Transplants. 
I believe that our work in schools and universities, providing knowledge and making people aware of the cause. (P5 - Rio Grande do Sul)

Carry out campaigns in schools and companies to clarify all doubts present in the act of donating. (P6 - Paraná)

Information for health professionals and the community. (P6 Santa Catarina)

Likewise, nurses believe that educational actions aimed at training professionals are also a viable alternative to increase the rates of organ and tissue donation, according to their speeches.

In addition to semi-annual on-site training on forms and interview. (P1 - Rio Grande do Sul)

Training, awareness lectures, feedback on results and objectives. (P1 Paraná)

Well-structured processes and trained staff. (P2- Paraná)

Dissemination and better clarification of professionals working in critical areas. (P3 - Santa Catarina)

Yes, the State of Paraná has excellent logistical support, invests in education and technological density. (P4 - Paraná)

Conducting the interview. (P6 - Rio Grande do Sul)

The importance of training the team to use the same language. (P8 Santa Catarina)

I think there is a lack of more engagement from the hospital team members [...] more training. (P7 - Paraná)

\section{DISCUSSION}

One of the challenges faced by CIHDOTT nurses is to transpose the reductionist vision of this patient declared as dead and to recognize them as a human being who deserves respect and reverence in being potential to save other lives. The complexity of patient care in $\mathrm{BD}$ is to become aware that they are not a dichotomous being, that is, either dead or alive, but incorporates life and death simultaneously ${ }^{(20)}$.

In addition, it is also necessary to envision the hospital environment as a whole: the CIHDOTT nurse, the potential organ donor, the family and all the elements that constitute this ecosystem space. This whole set is interrelated, and its components influence and enable positive and/or negative reactions. In this way, they can enable negative influences on support and care provided to the possible donor and their family.

With this critical and reflective look, it is feasible to incorporate actions to provide influences capable of increasing the rates of organ donations for transplants. This ecosystem principle of unity/wholeness is necessary, as it allows to see the world, the surrounding real space and where it is inserted, in which the component elements are related and interact with each other, exercising influences, changes and transformations ${ }^{(2)}$.
Supporting family members (Table 1, variables 1.2, 1.3, 1.4) is an action that makes it possible to increase the rates of organ donation, which is also evidenced in the literature ${ }^{(3,20-21)}$, in which the scenarios with greater action focused on support for family members have greater records of organ donation. It stresses whether, in this way, that the eco-systemic principle of nursefamily interaction is essential to achieve the goal of organ donation, when staying in telephone contact, being present during the progress of the donation process.

The data found in these states demonstrate that there are statistical differences with regard to the support provided to family members (Table 1, variables 1.4, 1.6), and it can be inferred that these actions, combined with the availability of physical resources (Table 1, variables 1.1,1.9), can determine the success in obtaining organs in the states of Paraná and Santa Catarina, when compared to Rio Grande do Sul.

Thus, care involves humanized assistance not only for the patient, but also for his family ${ }^{(4,15)}$. The care provided to patients in $\mathrm{BD}$ and their family is like that provided to other patients and requires health professionals (in this case, the nurse), sensitivity, involvement, empathy, attentive eye, keen perception and scientific knowledge. This form of care can guarantee the patient and the family an effective assistance ${ }^{(20)}$.

For this purpose, in welcoming the family, communication is used (Table 1, variables 1.2 and 1.4), which is seen as a strengthening point in the face of ethical conflicts experienced by family members ${ }^{(3)}$. Enhancing effective communication can facilitate and mobilize the elements involved with families, generating healthy relationships in the system / environment in which they are inserted. When considering the complexity that permeates the entire organ donation and transplantation process, the nurse not only understands, but is sensitized to the people involved ${ }^{(21)}$.

It is also necessary to follow a specific methodology for conducting an interview (Table 1, variable 1.5) can open the way for professional nurses to help families reach a decision on whether or not to donate organs (Table 1, variable 1.7). It can also help nurses to avoid their suffering when making a difficult request, at a difficult time. (Table 1, variables 1.7, 1.8, 1.10).

The organization of care practices by CIHDOTT nurses consists of identifying the needs of the potential donor, implementing, evaluating and monitoring the results of care. However, the difference is the speed with which the nurse faces the care process for this patient, as the pathophysiological and hemodynamic changes related to $\mathrm{BD}$ are variable and are directly related to the success of the organ donation and transplantation process ${ }^{(20)}$. The ecosystem is characterized by the dynamism of its organisms - in which the human being is one of the members - and for being a flexible network, in constant search for dynamic balance ${ }^{(22)}$.

A Brazilian study ${ }^{(4)}$ shows that one of the difficulties is related to assistance teams, among which the idea that the donation process is an exclusive task of CIHDOTTs teams is common, when in fact it is a jointly developed work. When welcoming families, we consider that organ donation permeates the hospital environment and, therefore, needs to be strengthened through the bond and trust of these families in the teams that work in the process $^{(3,5)}$. Even though CIHDOTTs have specific duties, this does not prevent other hospital teams from welcoming and supporting 
families in an extremely painful moment, as thinking about the hospital environment is reflecting on an ecosystem, where, as such, everything is interrelated and mutually influenced.

Another action pointed out was the media and dissemination campaigns, which, in the nurses' understanding, can be a stimulator of the increase in the rates of obtaining organs and tissues for transplant purposes (Table 2, variables 2.1 and 2.2 and 2.4), which confirmed by the statements of the participants of this study in the results of the qualitative research. Education is a determining factor for the success or failure of the donation and transplantation process: courses, lectures and training aimed at society, family and professionals are strategies to improve organ donation rates ${ }^{(20)}$.

It is a consensus in the literature ${ }^{(3-5,23)}$ that the lack of knowledge on the part of family members is also a major hindrance to the work of CIHDOOT nurses, especially when this family member is approached inappropriately. This is because, in most cases, there is no acceptance of $\mathrm{BD}$, leaving the nurse responsible with a humanized and enlightening approach, which is not always easy if this professional is not adequately prepared. In this sense, a study conducted in $\mathrm{Brazi}^{(23)}$ pointed out that the reason for the most frequent refusal was the ignorance of the responsible family member about the donor's opinion.

Nurses believe that educational actions aimed at training professionals are a viable alternative to increase the rates of organ and tissue donation. The training of professionals in the ICU and other sectors, as well as learning and improvement in practice, are facilitators to achieve better donation rates ${ }^{(20)}$. Even so, the results show that only $15.2 \%$ (Table 2 , variable 2.1 ) always perform activities aimed at training professionals.

It is possible to perceive that educational actions aimed at the intra-hospital environment are more frequently mentioned (Table 2, variables $2.1,2.3$ ) than educational actions directed at extra-hospital environments (Table 2, variable 2.2), in which 55\% of respondents rarely or never perform such actions in schools or universities. In fact, massive dissemination to society in favor of organ donation is carried out by governments. In spite of this, the applicability of a social marketing campaign showed that one of the possible explanations for the low effectiveness of organ donation may be related to the incredulity of the people in the message sender, that is, the government agencies ${ }^{(24)}$. Another Brazilian study ${ }^{(25)}$ concluded that campaigns in favor of organ donation are punctual, with no continued actions identified, corroborating the research findings.

The organ donation process is one of the most complex circumstances that occur in the sectors of care in ICUs, urgencies and health emergencies, and the maintenance of the potential donor is a situation that requires knowledge and preparation of the team. Confirming this fact, one of the difficulties faced by the CIHDOTT team is related to the lack of skill and training of nurses ${ }^{(4)}$.

The lack of knowledge and skill of the professional nurse clearly reflects on the development of his work, negatively impacting the donation process when he is insecure and/or not very effective within the ICU. However, difficulties can be minimized through continuing education ${ }^{(4)}$, which would reduce errors, facilitate practical learning and, consequently, favor the possibility of increasing organ and tissue donation rates.

\section{Study limitations}

Taking into account the continental extent of Brazil, this study had as its main limitation the scope of the data exclusive to the South Region, with the states presenting similar characteristics to each other, so further studies are needed in other areas of the country.

\section{Contributions to nursing, health or public policy}

The results of this investigation contribute to the strengthening of knowledge in the field of nursing, while pointing out viable actions to be developed for a successful program of organ and tissue donation for transplantation.

\section{CONCLUSIONS}

The actions identified by the research participants refer to the reception of the family, media campaigns and dissemination to society, which, in general, are linked to the training of professionals and have the possibility of becoming factors that encourage donation of organs and tissues. It was also evidenced that the support received by the family, through the actions of nurses from CIHDOTTs, such as communication and monitoring throughout the process, establishes relationships capable of generating feelings of trust and represents an important influence in the decision regarding the donation.

\section{REFERENCES}

1. Bertalanfy LV. Teoria geral dos sistemas. Petrópolis (RJ): Vozes; 2013. 361p.

2. Siqueira HCH, Thurow MRB, Paula SF, Zamberlan C, Medeiros AC, Cecagno D, et al. Health of human being in the ecosystem perspective. Rev Enferm UFPE[Internet]. 2018 [cited 2020 May 20];12(2):559-64. Available from: https://periodicos.ufpe.br/revistas/revistaenfermagem/ article/view/25069

3. Amaral APS, Silva JM, Santana LP, Vieira SNS, Anjos TDSN. Desafios encontrados no processo de doação de órgãos: relato de experiência. Lecturas: Educ Fís Deport [Internet]. 2018 [cited 2020 May 20];23(244):86-97. Available from: https://www.efdeportes.com/efdeportes/ index.php/EFDeportes/article/view/288

4. Basso LD, Salbego C, Gomes IEM, Ramos TK, Antunes AP, Almeida PP. Difficulties faced and actions evidenced in the nurses' performance regarding organ donation: integrative review. Cienc Cuid Saude [Internet]. 2018 [cited 2020 May 18];18(1)e4. Available from: http:// periodicos.uem.br/ojs/index.php/CiencCuidSaude/article/view/42020/pdf 
5. Pauli J. Doação organizacional em face ao mercado de órgãos: uma análise do modelo brasileiro de transplantação. Nova Economia [Internet]. 2019[cited 2020 May 18];29(1):339-63. Available from: https://www.scielo.br/pdf/neco/v29n1/1980-5381-neco-3528.pdf

6. Organização Mundial da Saúde (OMS). Trasplante de órganos y tejidos humanos. 63. a Asamblea Mundial de La Salud. Genebra. 2010.

7. Presidência da República (BR). Casa Civil. Decreto n 8.783 de 6 de junho de 2016. Dispõe sobre a remoção de órgãos, tecidos e partes do corpo humano para fim de transplante e tratamento. Brasília (DF); 2016.

8. Groot J, Vernooij-Dassen M, Vries A, Hoedemaekers C, Hoitsma A, Smeets W, et al. Intensive care staff, the donation request and relatives' satisfaction with the decision: a focus group study. BMC Anesthesiology. 2014;(14)52. https://doi.org/10.1186/1471-2253-14-52

9. Czerwinski J, Danek T, Trujnara M, Parulski A, Danielewcis R. System of donor hospital transplant coordinators maintained and financed by national transplant organization improves donation rates, but it is effective only in one half of hospitals. Transplant Proceed. 2014;(46)8:2501-4. https://doi.org/10.1016/j.transproceed.2014.09.023

10. Kocaay AF, Celik S, Eker T, Oksuz NE, Akyol C, Tuzuner A. Brain death and organ donation: knowledge, awareness, and attitudes of medical, law, divinity, nursing and communication students. Transplant Proceed. 2015;(47)5:1244-8. https://doi.org/10.1016/j. transproceed.2015.04.071

11. Camut S, Baumann A, Dubois V, Ducrocq X, Audibert G. Non-therapeutic intensive care for organ donation: $a$ healthcare professionals' opinion survey. Nurs Ethics. 2016;(23)2:191-202. https://doi.org/10.1177/0969733014558969

12. Foresberg A, Flodén F, Lennerling A, Karlsson V, Nilsson M, Fridh I. The core of after death care in relation to organ donation: a grounded theory study. Intensive Crit Care Nurs. 2014;(30)5:275-82. https://doi.org/10.1016/j.iccn.2014.06.002

13. Von Elm E, Altman DG, Egger M, Pocock SJ, Gotzsche PC, Vandenbroucke JP, STROBE Initiative. The Strengthening the Reporting of Observational Studies in Epidemiology (STROBE) statement: guidelines for reporting observational studies. J Clin Epidemiol. 2008;61(4):3449. https://doi.org/10.1016/j.jclinepi.2007.11.008

14. Creswell JW, Clark VP. Pesquisa de Métodos Mistos. 2a ed. Porto Alegre (RS); Penso: 2013.

15. Associação Brasileira de Transplante de Órgãos (ABTO). Dimensionamento dos Transplantes no Brasil e em cada estado 2012-2019. Registro Brasileiro de Transplante. 2019.

16. Mallette M, Barone D. On using Google forms. Reading Teacher. 2013;66(8):625-630. https://doi.org/10.1002/TRTR.1169

17. Djenno M, Inusa GM, Pho A. From paper to pixels: using Google Forms for collaboration and assessment. Library Hi Tech News. 2015;32(4): 9-13.

18. Gil AC. Amostragem na pesquisa social. Métodos e técnicas de pesquisa social. 6a ed. São Paulo (SP): Atlas; 2010. p.109.

19. Bardin L. Análise de conteúdo. São Paulo; 2011. 229p.

20. Magalhães ALP, Erdmann AL, Sousa FGMD, Lanzoni GMDM, Silva ELD, Mello ALSFD. Meaning of nursing care to brain dead potential organ donors. Rev Gaúcha Enferm. 2018;39:e2017-0274. https://doi.org/10.1590/1983-1447.2018.2017-0274

21. Tolfo FD, Camponogara S, Montesinos MJL, Beck CLC, de Lima SBS, Dias GL. The role of nurses in the intra-hospitalar organ and tissue donation commission. Rev Enferm UERJ. 2018;(26):273-85. https://doi.org/10.12957/reuerj.2018.27385

22. Medeiros EDSM, Bomfim AT. Enfermagem e a visão ecossistêmica da saúde. Rev Ciênc Saúde O Baiano [Internet]. 2016 [cited 2020 Jun 25];1(1):46-59. Available from: http://fasb.edu.br/revista/index.php/higia/article/view/106/92

23. Aranda RS, Zillmer JGV, Gonçalves KD, Porto AR, Soares ER, Geppert AK. Perfil e motivos de negativas de familiares para doação de órgãos e tecidos para transplante. Rev Baiana Enferm. 2018;32:e27560. https://doi.org/10.18471/rbe.v32.27560

24. Rezende LBO, Sousa VC, Pereira JR, Rezende LO. Doação de Órgãos no Brasil: uma análise das campanhas governamentais sob a perspectiva do marketing social. Braz J Mark BJM.2015;14(3):306-18. https://doi.org/10.5585/remark.v14i3.2902

25. Macedo CM, Veloso C, Rodrigues LC. Social marketing and organ donation: a study with declared donors. Braz J Develop. 2019;5(8):1353659. https://doi.org/10.34117/bjdv5n8-150 